\title{
Survey of Avian Species Diversity in Bali, Taraba State Nigeria
}

\author{
Cletus A. Ukwubile ${ }^{1 *}$, Mathias S. Bingari ${ }^{2}$., Johnbless E. Odey ${ }^{3}$ \\ ${ }^{1,3}$ Department of Science Laboratory Technology, Federal Polytechnic Bali, Nigeria. \\ 2. Department of Biological Sciences, Taraba State University, Jalingo, Nigeria.
}

\begin{abstract}
Birds are found almost everywhere in the world from pole to equator. They occur on land, sea and fresh water, and in every habitat, from the lowest deserts to the highest mountains, and they are used for various purposes in all aspects of life. The present study was carried out in order to determine avian species diversity in Bali town, Taraba State, Nigeria. Field survey was carried out from January, 2016 to January, 2017 in selected areas in Bali town's surrounding vegetations to know the species of birds that are found in these areas. Locations sampled were Sabon-Dale, Angwar Tiv/Mission, Behind Polytechnic Admin. offices (Rest House), Polytechnic Students Hostels, Inside Bali town, Daniya, and Behind Bali River. A total of 65 species of birds belonging to 39 Families, and 17 Orders were surveyed. Order Passeriformes were the most abundance with 16 families (40\%) and 26 species(39.39\%), followed by Order Columbiformes with one Family (2.5\%) and 7 species (10.60\%). The Orders Trogoniformes, Procellariformes, Musophagiformes, Caprimulgiformes, Gruiformes, and Suliformes were the least abundance species. Among the birds surveyed, only 10 species were aquatic birds, and were found behind Bali river. Two endemic birds were found, these were Adamawa turtle dove (Streptopelia hypopyrrha) and Prince Raspoli's turaco (Turaco ruspolii) as well as one endangered species Narina trogon (Apaloderma narina). The study showed that Bali town have rich avian fauna which are majorly Passeriformes. The reason for this increase in avian species diversity was due to low rate of urbanization in Bali town, and the presence of abundant grain crops which served as food to the birds, because most of them are pests of crops.
\end{abstract}

Keywords: Avian species, diversity, Passeriformes.

\section{INTRODUCTION}

Birds are found almost everywhere in the world from pole to equator. They occurred on land, sea and fresh water, and eventual every habitat, from the lowest deserts to the highest mountains. Human knowledge of birds diversity are driven by fundamental bio-geographic factors. With tropical countries (especially in west Africa) supporting the highest species abundance. Birds (Class Aves) are a group of endothermic vertebrate, characterized by feathers beak (mouth-part) without teeth, the laying of hard- shelled eggs, high metabolic rates, a four chambered heart and a light weight but strong skeleton. Birds are a diverse group, and their bright colours distinct songs and calls and showy displays add enjoyment to our lives. Birds are very visible quite common and offer easy opportunities to observes their diverse plumage and behaviors. Birds are popular to many who pursue wildlife watching and monitoring activities. Birds can be used as an agents of biological controls consuming of hundreds of insect many of which considered an a pest to our crops with even mosquitoes, Japanese beetle and European corn borer moth are been feed by birds. They can be used as bioindicators, without birds, the effects of pollution would not have been visible in the 1950s sand 1960s United States of America. Birds diets are varied and often include: nectar, fruit plants seeds carrion and various small animals including other birds (Gill et al 1995).

Birds have no teeth their digestive system in adapted to process un-masticated food items are swallowed whole. Birds that employ many strategies to obtained food are called generalist while others that concentrate time and effort on specific food item or have a single strategy to obtained food are considered specialists (Gill et al 1995).

Bali is situated on the upper bank of river Taraba a major tributary of river Benue at an attitude of about $480 \mathrm{~m}$ above sea level it is at some 150 kilometers away from Taraba State Capital (Jalingo) by virtue of its location in water shed area of Benue State and proximity to Taraba State. (River Taraba). The Taraba Federal Polytechnic Bali is located in Bali town, which has a prominent role to play in the 
development of agro industrial sector and provision of the technical requirement of man power to North-east region and Nigeria at large. The annual rainfall for Bali is between 100-120 mm. Rainfalls are experienced for the above 7 months each year with mean monthly rainfall recorded of above 220 $\mathrm{mm}$. The town it is about $50 \mathrm{Km}$ away from Gashaka Gumpti National Park where it also boost tourism. The major occupation of Bali people is farming of crops such as cassava, sorghum, maize, millet, groundnut, bean, vegetables, soya bean, rice and yam as well as fishing.

This present study was aimed at surveying avian species found in Bali town with a view to identifying those probably thought to be endemic or extinct.

\section{MATERIALS AND MeTHODS}

\subsection{Field Survey}

Field survey was carried out between 5-7am and 5-7 pm each day from $9^{\text {th }}$ of January, 2016 to $31^{\text {st }}$ of December, 2016 in the following areas: Federal Polytechnic permanent site, Sabon-dale, Behind Rest House, Students hostel, Angwar Mission/Tiv, Behind Bali river, Daniya and Central Primary School to survey avian species found in these areas.

\subsection{Ecological Photographic Shot}

Binocular was collected from the Department of Biological Sciences, Taraba State University viewing birds while cannon camera was used for capturing their images. With the aid of "Birds Field Guide" the birds were accurately described in terms morphology as well as sounds and flight patterns(Mason, 1996; Bayard and Elphick, 2010; Batary and Baldi, 2004; Freemark and Collins, 1992).

\subsection{Study of Species Abundance}

Abundance of birds species were studied using Peterson-Lincoln estimation index and Point count techniques (Lincoln, 1930). Briefly, Peterson-Lincoln estimation index: These Method was carried out by using a mist-net to capture birds. After capturing the birds a tag was put on the birds using aluminum and marking tapes and then released. After seven days, a recaptured was made again. The recaptured marked birds were also captured along side with an unmarked ones. The population of the birds were then calculated using the formula below:

$\mathrm{S} / \mathrm{R}=\mathrm{N} / \mathrm{M}$ where $\mathrm{N}=\mathrm{Ms} / \mathrm{R}$ (Peterson, 1896; Lincoln,1930).

Point count techniques: This method was carried out by standing in a particular place and count a species of birds repeatedly for seven days and for 32 weeks and record their population according to their Order, Families and species as seen in the field book (Sighn et al., 2013; Cunning and Johnston, 2016).

\subsection{Statistical Analysis}

Data obtained were represented as charts, tables and percentages.

\section{RESULTS AND DISCUSSION}

Table1. Birds in Bali with their Status According to LUCN (2013)

\begin{tabular}{|c|c|c|c|c|}
\hline Common name & Scientific name & Order & Family & Status \\
\hline Village weaver & Ploceus cucullatus & Passeriformes & Ploceidae & $\mathrm{LC}^{* *}$ \\
\hline Northern red bishop & Euplectes franciscanus & Passeriformes & Ploceidae & $\mathrm{R}^{* *}$ \\
\hline Village indigo & Vidua Chalybeata & Passeriformes & Viduadae & $\mathrm{LC}^{\text {*** }}$ \\
\hline Pin- tailed whydah & Vidua macroura & Passeriformes & Viduadae & $\mathrm{LC}^{\text {*** }}$ \\
\hline Red- crowned quelea & Quelea quelea & Passeriformes & Ploceidae & $\mathrm{LC}^{* * *}$ \\
\hline Ash -sported quelea & Quelea quelea & Passeriformes & Ploceidae & $\mathrm{LC}^{*}$ \\
\hline African seed-eater & Crithagra gularis & Passeriformes & Fringillidae & $\mathrm{LC}^{* * *}$ \\
\hline Yellow- fronted canary & Crithagra mozabicus & Passeriformes & Fringillidae & $\mathrm{LC}^{* *}$ \\
\hline Cape glossy starling & Lamprotornis nitens & Passeriformes & Sturnidae & RM \\
\hline African thrush & Turdus pelios & Passeriformes & Turdidae & $\mathrm{LC}^{\text {*** }}$ \\
\hline Garden warbler & Sylvia borin & Passeriformes & Sylviidae & $\mathrm{LC}^{* * * *}$ \\
\hline Eurasian black cap & Sylvia atricapilla & Passeriformes & Sylviidae & $\mathrm{RM}^{* * *}$ \\
\hline African golden oriole & Oriolus auratus & Passeriformes & Oriolidae & $\mathrm{RM}^{* *}$ \\
\hline Isabelline shrike & Lanius isabellinus & Passeriformes & Laniidae & $\mathrm{UC}^{*}$ \\
\hline Yellow-crowned gonolek & Laniarius barbarous & Passeriformes & Malaconotidae & UC** \\
\hline
\end{tabular}


Survey of Avian Species Diversity in Bali, Taraba State Nigeria

\begin{tabular}{|c|c|c|c|c|}
\hline Orange -breasted sunbird & Anthobaphes violacea & Passeriformes & Nectariniidae & LC** \\
\hline White Crowed robin-chart & Cossypha albicapilla & Passeriformes & Musciecapidea & $\mathrm{LC}^{*}$ \\
\hline Blue-headed sunbird & Cyanometra verticalis & Passeriformes & Nectariniidae & $\mathrm{LC}^{*}$ \\
\hline Splendid sunbird & Cinnyris coccinigastrus & Passeriformes & Nectariniidae & $\mathrm{LC} * * *$ \\
\hline African hill warbler & Pseudoalcippe abyssinica & Passeriformes & Sylviidae & $\mathrm{LC} * * *$ \\
\hline Fire finch blue billed & Lagonosticta rubricata & Passeriformes & Estrildidae & $\mathrm{LC}^{* *}$ \\
\hline Black- headed Gonolek & Laniarius barbarous & Passeriformes & Malaconotidae & $\mathrm{LC}^{* * *}$ \\
\hline Piapiac & Ptilostomus afer & Passeriformes & Corvidae & $\mathrm{RM}^{* *}$ \\
\hline Pied crow & Carvus albus & Passeriformes & Corvidae & $\mathrm{RM}^{*}$ \\
\hline Yellow- billed kite & Milvus aegypstius & Accipitriformes & Accipitridae & $\mathrm{R}^{*}$ \\
\hline Black-shouldered kite & Elanus axillaris & Accipitriformes & Accipitridae & $\mathrm{R}^{*}$ \\
\hline White- tailed kite & E. Leucurus & Accipitriformes & Accipitridae & $\mathrm{R}^{*}$ \\
\hline Swallow -tailed kite & Elonoides forficatus & Accipitriformes & Accipitridae & $\mathrm{R}^{*}$ \\
\hline Red kite & Mivlus mivlus & Accipitriformes & Accipitridae & $\mathrm{R}^{* *}$ \\
\hline Blue -breasted king fisher & Hycyon malimbica & Coraciifromes & Alcedinidae & $\mathrm{R}^{* *}$ \\
\hline Wood land King fisher & H. senegalensis & Coraciifromes & Alcedinidae & $\mathrm{R}^{*}$ \\
\hline Greater honey guide & Indicator indicator & Piciformes & Picidae & $\mathrm{LC}^{\text {*** }}$ \\
\hline Downy wood pecker & Dryobates pubescens & Piciformes & Picidae & $\mathrm{LC}^{* * *}$ \\
\hline Africa scope owl & Otus Senegalensis & Strigiformes & Strigidae & $\mathrm{LC}$ \\
\hline Born owl & Tyto alba & Strigiformes & Tytonidae & $\mathrm{LC}^{\text {*** }}$ \\
\hline Brown nightjar & Caprimulgus & Caprimulgiformes & Caprimulgidae & $\mathrm{LC}^{* *}$ \\
\hline Cattle egret & Bubucus ibis & Pelecaniformes & Aredeidae & $\mathrm{LC}^{* *}$ \\
\hline African spon-bill & Platalea alba & Pelecaniformes & Threskiornithisdae & $\mathrm{UC}^{*}$ \\
\hline Tricolored- hero & Egret tricolor & Pelecaniformes & Ardeidae & $\mathrm{RM}^{* *}$ \\
\hline Grey heron & Ardea cinerea & Pelecaniformes & Ardeidae & $\mathrm{RM}^{*}$ \\
\hline Black-headed heron & A. melanocephala & Pelecaniformes & Aredeidae & $\mathrm{RM}^{*}$ \\
\hline Klaas's cuckoo & Chrysoccyx klass & Cuculiformes & Cuculidae & $\mathrm{RM}^{* *}$ \\
\hline Greater-blue turaco & Corythaeola cristata & Musophagngiformes & Musophagidae & $\mathrm{M}^{* *}$ \\
\hline Turaco rupolis's & Prince-ruspolis & Musophagiformes & Musophagidae & ED** \\
\hline Senegal coucal & Centropus senegalensis & Culculiformes & Cuclidae & $\mathrm{VC} * *$ \\
\hline White -faced whistling duck & Dendrocygna vduat & Anseriformes & Anatidae & $\mathrm{VC} * *$ \\
\hline Galapogos shearer water & Puffinus subalaris & Procellariiformes & Procellaridae & $\mathrm{LC}^{* * *}$ \\
\hline Africa jacana & Actophilornis africanus & Charadriiformes & Jacanidae & $\mathrm{LC}^{* *}$ \\
\hline African darter & Anhinga rufa & Suliformes & Anhingidae & $\mathrm{R}^{*}$ \\
\hline Long-toed lapwing & Vanellus crassirostris & Charadriiformes & Charadriidae & $\mathrm{RM}^{* *}$ \\
\hline Yellow-billed coucal & Centropus americanus & Cuculliformes & Cuculidae & $\mathrm{RM}^{* *}$ \\
\hline Oystercatcher & Haematopus moquini & Charadriiformes & Charadriidae & $\mathrm{R} * *$ \\
\hline Narina trogon & Apaloderma narina & Trogoniformes & Trogonidae & $\mathrm{M}^{* *}$ \\
\hline Africa black swift & Apus barbatus & Apodiformes & Apodidae & $\mathrm{M}^{* *}$ \\
\hline Bush fowl & Francolinus bicalcaratus & Galliformes & Phasicianoidae & $\mathrm{R}^{*}$ \\
\hline Guinea fowl & Numida meleagris & Galliformes & Numididae & $\mathrm{R}^{*}$ \\
\hline African crake & Crex egregia & Gruiformes & Rallidae & $\mathrm{R}^{*}$ \\
\hline Red- eyed dove & Streptopelia semitorquata & Columbiformes & Columbidae & $\mathrm{R}^{*}$ \\
\hline Mourning collared dove & Streptopelia decipiense & Columbiformes & Columbidae & $\mathrm{R} * *$ \\
\hline Lemon dove & Columba larvata & Columbiformes & Columbidae & $\mathrm{R}^{* *}$ \\
\hline Wood dove & Turtur chalcospilos & Columbiformes & Columbidae & $\mathrm{R} * * *$ \\
\hline Adamawa turtle dove & $\begin{array}{l}\text { Streptopelia } \\
\text { hypopyrrha }\end{array}$ & Columbiformes & Columbidae & ED* \\
\hline
\end{tabular}

$L C=$ least concern, $R=$ Residence, $R M=$ Residence Migratory, UC=Uncommon, $V C=$ very common, $E D=$ Endangered, $*=$ birds found in one area, $* *=$ Birds found in two areas of surveyed, $* * *=$ Birds found in all areas of surveyed.

Table2. Percentage Distribution of Avian Fauna in Bali

\begin{tabular}{|l|l|l|l|l|}
\hline Order & No of Family & (\% Abundance) & No of species & (\% Abundance) \\
\hline Passeriformes & 16 & $(40.00)$ & 26 & $(39.39)$ \\
\hline Columbiformes & 1 & $(2.50)$ & 7 & $(10.60)$ \\
\hline Accipitriformes & 1 & $(2.50)$ & 5 & $(7.57)$ \\
\hline Pelecaniformes & 2 & $(5.00)$ & 5 & $(7.57)$ \\
\hline Coraciiformes & 1 & $(2.50)$ & 2 & $(3.03)$ \\
\hline Piciformes & 2 & $(5.00)$ & 2 & $(3.03)$ \\
\hline
\end{tabular}


Cletus A. Ukwubile et al.

\begin{tabular}{|l|l|l|l|l|}
\hline \hline Strigiformes & 2 & $(5.00)$ & 2 & $(3.03)$ \\
\hline Cuculiformes & 2 & $(5.00)$ & 3 & $(4.55)$ \\
\hline Procellariformes & 1 & $(2.50)$ & 1 & $(1.52)$ \\
\hline Musophagiformes & 1 & $(2.50)$ & 2 & $(3.03)$ \\
\hline Charadriiformes & 3 & $(7.50)$ & 3 & $(4.55)$ \\
\hline Caprimulgiformes & 1 & $(2.50)$ & 1 & $(1.52)$ \\
\hline Trogoniformes & 1 & $(2.50)$ & 1 & $(1.52)$ \\
\hline Apodiformes & 1 & $(2.50)$ & 1 & $(1.52)$ \\
\hline Galliformes & 2 & $(5.00)$ & 2 & $(3.03)$ \\
\hline Gruiformes & 1 & $(2.50)$ & 1 & $(1.52)$ \\
\hline Suliformes & $(2.50)$ & 1 & $(1.52)$ \\
\hline
\end{tabular}

From the table 2 above it showed that out of 23 Orders of avian species globally, 17 Orders were surveyed in Bali while, of 142 Families of the Class Aves, 40 Families were surveyed within the period. Also out of 2,057 genera of birds globally, 100 genera were surveyed in Bali, Taraba State, Nigeria, 150 species were surveyed out of 9,702 species of birds. These include: the endangered species like the Narina trogon (Apacoderma narina) Order Trogoniformes, Family Trogonidae which is described as uncommon in terms of status in the ecosystem, turaco Order Musophagiformes, Family Musophagidae popularly known as Prince ruspoli's turaco. The distribution of these avian fauna was determined by seasonal variation in most places (Ezealor, 2002) and in Bali. This is because the birds were found in abundance in the months of July and August, and were rarely seen in the dry season mainly due to lack of foods and harsh winter temperatures coupled with intense heat in Bali during these period. It has been reported that seasonal variations, presence of food, and harsh climatic conditions affect avian species diversities (Martin and Svingen, 2010). This is the same reasons why some birds were surveyed at different months in Bali.

The least concern (LC) species were northern red bishop, Quelea, and village weaver. These avian fauna form the larger population in the Order Passeriformes due to abundance grains in this area since cereals such as rice, guinea corn, millet, etc, are the major cash crops cultivated in Bali. Thus, these birds are the major pest of crops in Bali, Taraba State. The presence of an endangered species of birdAdamawa turtle dove (Streptopelia hypopyrrha) in this area indicates the comfortability of Bali as excellent eco-zone for avian fauna.

Of all the birds surveyed within these periods, the aquatic birds ranked the lowest. This unarguably is because Bali is not known as a river-prone area so the presence of water birds were by a way of migration. As a result, birds like African jacana, oyster catcher, white-billed whistling duck, and water shearer surveyed in Bali were as a result of migration. However, bird such as the great grey heron were resident in Bali all throughout the sampling periods. It is possible that this great bird obtain its food (fish, rodent, and small mammals) by embarking on long flight to river sites of Sabon-Dale. Barrow and Demey (2004), showed that water birds have the capacity to embark on a long flight in search of foods especially during food shortage, and this was the case of the great grey heron and various species of owl and kites surveyed within these periods.

\section{CONCLuSion}

Our study showed that there are enormous species of birds in Bali which cut-across many Families and Orders; with members of the Order Passeriformes the dominant. These birds occupies various niche in many ecological zones in Bali ranging from grain eaters to flesh eaters. However, the study is concerned about the problem of rapid urbanization which has resulted in increase in deforestation that may lead to the disappearance of these avian fauna surveyed in Bali if not checked. Excessive falling of economic trees without immediate replacement might affect negatively the avian species diversity in Bali, unless there exist a regulation guiding the falling of trees such as "madrin" which is continually exploited for commercial purposes in Bali, Taraba State.

\section{ACKNOWLEDGEMENT}

We are thankful to Prof. A.U Ezealor for directing us, and Dr. Umar of the Department of Biological Sciences, Taraba State University Jalingo who lend us Binoculars used in this study. 


\section{REFERENCES}

Batáry, P.,and Báldi, A. (2004). Evidence of an edge effect on avian nest success. Conservation Biology; 18:389-400. http://dx.doi. org/10.1111/j.15231739.2004.00184.x

Bayard, T. S., and C. S. Elphick. (2010). How area sensitivity in birds is studied. Conservation Biology; 24:938-947. http://dx.doi. org/10.1111/j.1523- 1739.2010.01480.x

Borrow, N. and Demey, R. (2004). Birds of Western Africa. Published by Christopher Helm, London,510pp.

Cunningham, M., and Johnson, D.H.( 2016). What you find depends on where you look: responses to proximate habitat vary with landscape context. Avian Conservation and Ecology; 11(2):1. http://dx.doi.org/10.5751/ACE-00865-110201

Ezealor, A.U.(2002).Critical Sites for Biodiversity Conservation in Nigeria. Nigeria Conservation Foundation, Lagos, Nigeria, Pp. 53 - 54.

Freemark, K., and Collins, B. (1992). Landscape ecology of birds breeding in temperate forest fragments. Pp 443-454 In: Hagan, J.M., and Johnston,D.W., editors. Ecology and conservation of neotropical migrant landbirds. Smithsonian Institution Press,

Lincoln, F. C. (1930). "Calculating Waterfowl Abundance on the Basis of Banding Returns".United States Department of Agriculture Circular, 118, 1-4.

Martin, R., and Svingen, D.N. (2010). Bird status and distribution on the Sheyenne National Grassland Report to Dakota Prairie Grasslands. Internal report, U.S. Forest Service, Bismarck, North Dakota, USA.

Mason,D.(1996).Response of Venezuelan Understory Bird to Selective Logging, Enrichments Trips and Vine Cutting. Biotropica, 28:296-309.

Peterson, C. G. J. (1896). "The Yearly Immigration of Young Plaice Into the Limfjord From the German Sea", Report of the Danish Biological Station (1895), 6, 5-84

Sighn, L.M., Imran, A.S., and Bill, D.J. (2013). Factors affecting the distribution of White-tailed whydah in marsh lands. Journal of ecological conservation, 3(2):32-42.Washington, D.C., USA. 